Columbia Law School

Scholarship Archive

2020

\title{
Revising Boilerplate: A Comparison of Private and Public Company Transactions
}

Stephen J. Choi

New York University School of Law, stephen.choi@nyu.edu

Robert E. Scott

Columbia Law School, rscott@law.columbia.edu

G. Mitu Gulati

Duke University School of Law, gulati@law.duke.edu

Follow this and additional works at: https://scholarship.law.columbia.edu/faculty_scholarship

Part of the Banking and Finance Law Commons, Business Organizations Law Commons, Contracts Commons, Law and Economics Commons, Legal Profession Commons, and the Securities Law Commons

\section{Recommended Citation}

Stephen J. Choi, Robert E. Scott \& G. Mitu Gulati, Revising Boilerplate: A Comparison of Private and Public Company Transactions, 2020 WIS. L. REV. 629 (2020).

Available at: https://scholarship.law.columbia.edu/faculty_scholarship/2577

This Article is brought to you for free and open access by the Faculty Publications at Scholarship Archive. It has been accepted for inclusion in Faculty Scholarship by an authorized administrator of Scholarship Archive. For more information, please contact scholarshiparchive@law.columbia.edu. 


\title{
REVISING BOILERPLATE: A COMPARISON OF PRIVATE AND PUBLIC COMPANY TRANSACTIONS
}

\author{
ROBERT E. SCOTt, StePHEN J. CHOI, \& Mitu Gulati*
}

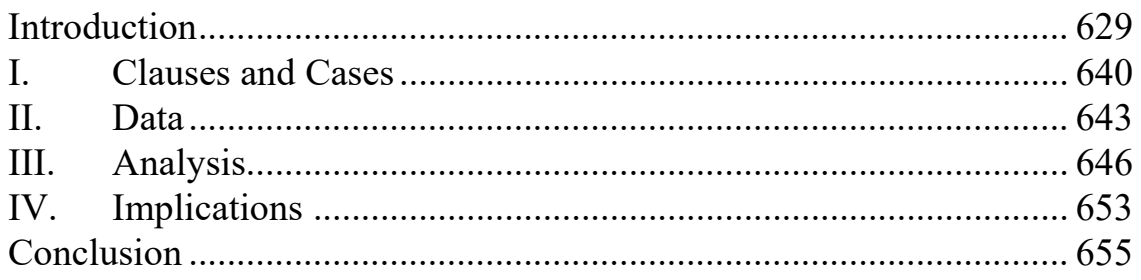

INTRODUCTION

The textbook model of commercial contracts between sophisticated parties holds that terms are proposed, negotiated and ultimately priced by the parties. Parties reach agreement on contract provisions that best suit their transaction with the goal of maximizing the joint surplus from the contract. The reality, of course, is that the majority of the provisions in contemporary commercial contracts are boilerplate terms derived from prior transactions and even the most sophisticated contracting parties pay little attention to these standard terms, focusing instead on the price of the transaction. ${ }^{1}$ With standard-form or boilerplate contracts, this dynamic of replicating by rote the terms from prior transactions is exacerbated when the contract terms are reproduced largely because the same term was successful in closing prior deals and, even more importantly, because the terms are part of the market standard. ${ }^{2}$ The end result is that suboptimal

At Columbia, NYU and Duke law schools, respectively. Thanks to Robert Anderson, Theresa Arnold, Sean Griffith, Caroline Gottschalk, Elisabeth de Fontenay, Claire Hill, Matt Jennejohn, Don Langevoort, Ann Lipton, Yaron Nili, Usha Rodrigues, Alan Schwartz and Glenn West for comments. Thanks also to Amanda Dixon and Madison Whalen for their exceptional work on the data collection front. Finally, a special thanks to the many lawyers who talked to us about their No Recourse contract terms.

1. E.g., Barak Richman, Contracts Meet Henry Ford, 40 HofSTRA L. ReV. 77, 79 (2011). More generally, on the ritual of copy and paste, see Claire Hill, Repetition, Ritual and Reputation: How do Market Participants Deal With (Some Kinds of) Incomplete Information, 2020 WIS. L. REV. 101.

2. For discussions of this reproduction dynamic, see Julian Nyarko, Stickiness and Incomplete Contracting: Explaining the Lack of Forum Selection Clauses in Commercial Agreements (2019) (unpublished manuscript), https://www.law.columbia.edu/sites/default/files/microsites/law-economicsstudies/nyarko_stickiness.pdf [https://perma.cc/HQ6F-24MD]; see also Anna Gelpern et al.,, If Boilerplate Could Talk: The Work of Standard Terms in Sovereign Bond Contracts, 44 LAW \& SOC. INQUIRY 617 (2019). 
terms can persist in boilerplate contracts unchanged for decades. Indeed, some standardized terms in boilerplate contracts may have lost any recoverable meaning - thus creating what we have called a contractual black hole. ${ }^{3}$ Here, courts may be practically incapable of recovering a plausible meaning that was attached to the standard terms by the contracting parties at the time the contract was drafted.

In prior research, we examined the phenomenon of stickiness of boilerplate terms in the specific commercial context of sovereign bond contracting. ${ }^{4}$ Among the more plausible reasons for the stickiness of standard terms in sovereign debt contracts are the presence of agency costs and coordination difficulties. ${ }^{5}$ Sovereign bond issuances are typically rote transactions where the parties driving the deal on both sides, government officials on the client side and investment bankers on the investor side, have short-term incentives to get the deals done at the cheapest front-end costs and are not concerned about boilerplate terms that are only relevant in the low probability event of default. ${ }^{6}$ These "client-side" and "investorside" agents are unlikely to be present when a default occurs, making the problems that may be caused by enforcement terms in the event of default even less salient at the time of contracting. In our research, we document that sophisticated commercial actors, even while fully cognizant that their contracts contained terms that subjected them to needless litigation risk, took years to revise those terms. ${ }^{7}$

The agency cost problem in sovereign bond issuances implicates a further set of agents - the elite lawyers who negotiate and draft the contracts for the issuers and investors and whose ethical responsibility is to draft contract terms that best reflect the deal to which the parties believe they have agreed. In our previous work, we described the incentive of these "lawyer-side" agents in the following terms: The private interests of the elite lawyers who dominate the sovereign bond market is to process bond issues at the least ex ante cost and as quickly as possible, notwithstanding expected default costs. ${ }^{8}$ This single-minded focus on reducing front-end contracting costs is simply a reflection of the fact that the "legal terms" for which the lawyers are responsible and that form the standard boilerplate are seen as immaterial to both sellers and buyers in the initial pricing of the bonds.

3. See Stephen J. Choi, Mitu Gulati \& Robert E. Scott, The Black Hole Problem in Commercial Boilerplate, 67 DuKE L.J. 1 (2017) (exploring how certain contracts are created and evolve over time) [hereinafter The Black Hole Problem].

4. Id.

5. $\quad I d$. at $59-66$.

6. Id.

7. See Choi, Gulati, \& Scott, supra note 3.

8. Mitu Gulati \& Robert E. Scott, The Three and a Half Minute Transaction: BoIlerplate AND the Limits of CONTRACT Design 10 (2013). 
All of the aforementioned agents viewed themselves as insulated from criticism as long as they utilized the standard forms. Innovation may be required by an exogenous shock, but any action to revise boilerplate was measured against the risk that the market might react negatively to a deviation from the market standard. ${ }^{9}$ Thus, absent some clear signal that there was going to be a market shift in the standard form, these agents were unwilling to act unilaterally. In the sovereign context, we found that when change finally occurred, it followed directly after a series of coordinating events in which senior lawyers and their clients met to discuss the imperative of revising the current standard form.

In analyzing these agency cost explanations for contract stickiness, it is important to recognize that there are two degrees of separation between agents and principals in sovereign bond contracting. ${ }^{10}$ The investors and the citizens of the sovereign state are separated by debt managers for the sovereign state and investment banks for the investors, each with imperfect incentives to revise contracts that overtime contain suboptimal terms. ${ }^{11}$ These agents may be subject to hyperbolic discounting: they may value the immediate benefits from the bond issue more than the discounted probability of an even more costly future default. ${ }^{12}$ These agents, however, are also the clients of the lawyers whose incentives to reflect their principals' interests are similarly imperfect. ${ }^{13}$ Thus, the lawyers representing the managers may also have inadequate incentives to react to changes in the environment that call for revision of standard form contracts. The challenge, therefore, is to find environments where these various agency costs are significantly different, so as to isolate their effects.

An important question that remains from our research on sovereign debt contracts, therefore, is whether contract term stickiness due to some combination of agency costs generalizes to other commercial settings in which the clients and investors are more directly engaged in monitoring the drafting behavior of their lawyers. ${ }^{14}$ A corollary question is the extent

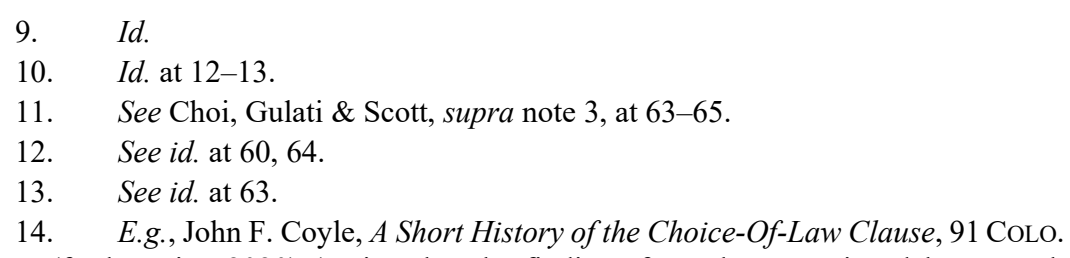
L. REV. (forthcoming 2020) (noting that the findings from the sovereign debt research might not generalize). Much of the stickiness research has focused on corporate bonds. See, e.g., Marcel Kahan \& Michael Klausner, Standardization and Innovation in Corporate Contracting (or "The Economics of Boilerplate”), 83 VA. L. REV. 713 (1997); John F. Coyle, Choice-of-Law Clauses in Corporate Bond Indentures, 13 CAP. MKTS. L.J. 152 (2018); Gus de Franco et al., Sticky Covenants (Mar. 2013) (unpublished manuscript), https://en-

coller.tau.ac.il/sites/nihul_en.tau.ac.il/files/media_server/Recanati/management/seminars/ 
to which some coordinating mechanism is necessary to induce widespread change.

To test the power of agency costs as an explanation for sticky contract terms, we focus on the No Recourse term, a standardized contract term common in commercial contracts. ${ }^{15}$ The No Recourse term in a commercial contract purports to prevent a party (often a creditor) holding a claim against a corporate entity from pursuing its claim against the individual assets of the shareholders, managers and other principals of the corporate entity. ${ }^{16}$ We compare two different commercial markets - the acquisition markets for private company transactions and public company bond deals.

The private company deals we analyze involve concentrated and motivated principals, typically private equity firms, that have the expertise and financial incentives to focus on the language of the contract terms in the obligations that the firm assumes. ${ }^{17}$ The investors in private company deals are also highly concentrated. We posit that client-side and investorside agency costs are low in private company deals. Prime examples of private company deals are single transaction Merger and Acquisition contracts, and particularly those involving deals made by private equity firms. ${ }^{18}$ The basic rationale is that the principals in the M\&A/Private Equity market have more at stake and are directly involved in the deals. ${ }^{19}$

account/sticky.pdf [https://perma.cc/3B6T-PZDS]; Marcel Kahan \& Mitu Gulati, Contracts of Inattention (Aug. 25, 2019) (unpublished manuscript), https://papers.ssrn.com/sol3/papers.cfm?abstract_id=3442355 .

15. We discuss below the differing versions of this clause over time (and the reasons for its continued presence as part of a standard debt contract). See infra text accompanying notes $46-56$.

16. Glenn West \& Natalie Smeltzer, Protecting the Integrity of the EntitySpecific Contract: The 'No Recourse Against Others' Clause-Missing or Ineffective Boilerplate, 67 Bus. LAw. 39, 40 (2011).

17. We sourced these private company deals from the private equity contract database available https://1.next.westlaw.com/Browse/Home/PracticalLaw/WhatsMarket/PrivateAcquisition Agreements?transitionType $=$ Default \& contextData $=($ sc. Default $) \&$ navId $=41995$ E7244D1 E9BA3F4AB01B29979127.

18. John Coates's work on M\&A contracts suggests the likelihood of such differences across the settings. See John Coates, Why Have M\&A Contracts Grown? Evidence From Twenty Years of Deals (Oct. 26, 2016) (unpublished manuscript), https://papers.ssrn.com/sol3/papers.cfm?abstract_id=2862019.

19. Within the field of M\&A contracting itself, there is a debate over the extent to which contract language is primarily the product of expert lawyering or blind copy/paste processes. See, e.g., John Coates, Darius Palia \& Ge Wu, Are M\&A Contracts Value Relevant to Bidder and Target Shareholders? (June 2019) (unpublished manuscript) https://papers.ssrn.com/sol3/papers.cfm?abstract_id=3201235; Robert Anderson \& Jeffrey Manns, Boiling Down Boilerplate in M\&A Agreements: A Response to Choi, Gulati \& Scott, 67 DuKE L.J. 219 (2019). 
As a result, their lawyer-agents pay more attention to the deal terms, including in particular the No Recourse term.

Public company bond deals, on the other hand, look similar to the sovereign bond contracting practices we have previously examined, with dispersed investors on the creditor side and dispersed shareholders on the debtor side. One difference between public company deals and sovereign bond contracting is that the managers of the corporate issuers in a public company bond issue may benefit from the No Recourse clause. This is so because the clause in this case gives those managers a measure of personal protection from liability (a characteristic not present in the sovereign deals studied in our prior work). Thus, the interests of the both the principals and the corporate managers, the client-side agents, are more aligned perhaps than in the sovereign debt context. What is key for our purposes, however, is that there is greater dispersion of interests in the public company setting (and therefore greater likelihood of agency issues) than in the private equity setting. ${ }^{20}$

In what follows, we compare the evolution of the No Recourse clause over roughly a decade and a half. This term is part of the boilerplate in both industries and has been subject to a number of exogenous shocks over this period. ${ }^{21}$ We examine whether its evolution is different in the two industries as a function of the exogenous shocks that hit both industries; shocks that have prompted calls to revise the standard No Recourse clause to better insulate managers and shareholders from personal liability for corporate obligations.

In a November 2011 article, Glenn West and Natalie Smeltzer, lawyers in the private equity group at Weil, Gotshal \& Manges, identified the contemporary relevance of the "No Recourse" provision that had been part of the boilerplate in corporate bond indentures since the turn of the 20 th century. ${ }^{22}$ The clause originated when shareholders under many U.S. state corporate laws faced the possibility of unlimited liability. ${ }^{23}$ The clause was an attempt to achieve limited liability via contract; a status that, by the middle of the last century, almost every U.S. state had provided to corporate entities by statute. ${ }^{24}$ By the mid 20th century, therefore, the clause had become largely useless and, indeed, the American Bar

20. For a finding, in a different setting, of superior drafting in private equity deals, see Adam Badawi \& Elisabeth de Fontenay, Contractual Complexity in Debt Agreements: The Case of EBITDA (June 20, 2019) (unpublished manuscript), https://papers.ssrn.com/sol3/papers.cfm?abstract_id=3455497.

21. Matthew Cain, Steven Davidoff Solomon \& Antonio Macias, Broken Promises: The Role of Reputation in Private Equity Contracting and Strategic Default, 40 J. CORP. L. 565 (2015).

22. See generally West \& Smeltzer, supra note 16.

23. Id. at 41-44.

24. Id. at 42-43. 
Association's project on model bond indentures said so. ${ }^{25}$ Yet, the drafters of indentures kept the clause as part of the boilerplate terms, and the ABA even provided a standard version of the clause to be used by the corporate transactional lawyers who seemed attached to it. ${ }^{26}$ As West \& Smeltzer tell the story, a potential use for the clause emerged again in the late 20th century when courts around the country began to exhibit an increased willingness to find shareholders and managers personally liable under either veil piercing equitable theories or tort theories for fraudulent misrepresentation. ${ }^{27}$ One potential avenue of defending against these claims, in situations where the source of the claim was a contractual relationship and there was a No Recourse provision in the contract, was to assert that the plaintiffs had contractually agreed not to bring such claims.

A set of cases from the late 1980s and thereafter from the federal and state courts in Delaware involving corporate bond indentures raised the issue of whether the traditional No Recourse clause barred only contract law claims arising out of the contract and not equitable claims (e.g., veil piercing) or claims arising in tort (e.g., fraud). ${ }^{28}$ Faced with the standard No Recourse provision that did not explicitly opt out of liability based on equitable and tort theories, these courts ruled that the traditional boilerplate No Recourse provision protected against contract-based liability only and not equitable or fraud claims. ${ }^{29}$ Those rulings invited speculation whether a non-standard No Recourse provision, tailored to explicitly disclaim liability for equitable and tort type claims, could have offered better protection for the defendants. Absent a public policy reason to constrain the parties from contracting out of personal liability-for example, instances of intentional fraud-basic principles of contract law would support judicial enforcement of a modified No Recourse clause that

25. Id. at $44-57$.

26. Id. at $56-57$.

27. See Peter B. Oh, Veil Piercing, 89 TEx. L. Rev. 81, 107-10 (2010) (describing the rise in the number of veil piercing cases since the 1970s). See also David H. Barber, Piercing the Corporate Veil, 17 Willamette L. ReV. 371 (1981); But see Robert B. Thompson, Piercing the Veil: An Empirical Study, 76 CORnELl L. REv. 1036, 1047-50 (1991) (failing to find a trend towards an increased likelihood of courts finding veil piercing).

28. West \& Smeltzer, supra note 16, at 57-62.

29. E.g., Simons v. Cogan, 549 A.2d 300 (Del. 1988) (stating that the standard "no recourse provision limits liability for breach of contract to Knoll, the issuing corporation") (internal quotations omitted); Mabon, Nugent \& Co. v. Tex. Am. Energy Corp., 1988 WL 5492, at*3 (Del. Ch. Jan. 27, 1988) (alter-ego claims not barred by standard No Recourse provision in indenture); Geyer v. Ingersoll Publ'ns Co., 621 A.2d 784, 793-94 (Del. Ch. 1992) (standard No Recourse provision in indenture does not bar an alter-ego claim); U.S. Bank N.A. v. U.S. Timberlands Klamath Falls, L.L.C., 864 A.2d 930, 950-51 (Del. Ch. 2004) (non-contractual claims not covered by "no recourse" provision); LaSalle Nat'l Bank v. Perelman, 141 F. Supp. 2d 451, 463 (D. Del. 2001) (No Recourse clause does not cover non-contract claims). 
excluded equitable and fraud claims. Further, standard theory would predict that lawyers drafting bond indentures would adjust to these decisions and revise their clauses to better protect their clients on the issuer side.

In a second set of cases from the mid-1990s to mid-2000s involving commercial contracts with limited liability provisions, the courts held (or suggested) that a standard No Recourse clause could indeed protect against more than pure contract claims; particularly if the tort or equitable claims arose out of the contractual relationship. ${ }^{30}$ These cases were from several different jurisdictions (including California, Wisconsin, Illinois and Hawaii) and provided further support for the foregoing conjecture. None of these cases involved a No Recourse clause that explicitly disclaimed liability for a broader set of circumstances than simply contract claims. Instead, the courts were willing to read the clauses broadly, unlike the courts in Delaware and New York. Nevertheless, the lesson of the cases is that a No Recourse clause drafted to explicitly disclaim the broader types of liability was likely to provide more protection for issuers than one drafted narrowly.

These cases eventually led lawyers at a number of firms, including Weil Gotshal and Gibson Dunn, to urge their clients and colleagues concerned about shareholder and managerial liability to revise their No Recourse clauses. ${ }^{31}$ We treat the time periods when there was increased pressure for revision as the shocks that drove change in contract language

30. E.g., Laeroc Waikiki Parkside, L.L.C. v. K.S.K. (Oahu) L.P., 166 P.3d 961, 984 (Haw. 2007) (holding that a No Recourse clause can waive tort claims as long as it was knowingly made and was not unconscionable); Farnham v. Superior Court, 70 Cal. Rep. 2d 85, 91 (Ct. App. 1997) (concluding that a limited liability provision protecting corporate employer worked to bar tort claim for defamation, among other claims); Hoosier Energy v. Amoco Tax Leasing, 34 F.3d 1310, 1316 (7th Cir. 1994) (finding that a No Recourse provision served as an effective protection against claims of unjust enrichment). See also West \& Smeltzer, supra note 16, at Section V (C) (discussing these cases).

31. In addition to West \& Smeltzer, supra note 16, at 70, see Andrew Cheng et al. (Gibson Dunn \& Crutcher), Lender Protections in Purchase Agreements: Negotiating Xerox Provisions, Strafford (Feb. 16, 2017), http://media.straffordpub.com/products/lender-protections-in-purchase-agreementsnegotiating-xerox-provisions-2017-02-16/presentation.pdf [https://perma.cc/K384-XF76]. For additional discussions of the so-called "Xerox Provisions," which included efforts to limit lender liability along the lines suggested by West \& Smeltzer, supra note 16, see also Troy Ungerman (Norton Rose Fulbright), Money Makes the World Go Round: Lender Protections in Leveraged Acquisitions, DeAL LAW Wire Blog (Aug. 31 2016), https://www.deallawwire.com/2016/08/31/money-makes-the-world-go-round-lenderprotections-in-leveraged-acquisitions/ [https://perma.cc/7JU8-VVXV]; DAVIS POLK, Client MemoranduM: ACQUisition FinANCING IN 2010-TrendS FrOM 20094 (Jan. 7 2010), https://www.davispolk.com/files/files/Publication/eaa17efb-5045-4c5a-a9ef0377d3a54477/Preview/PublicationAttachment/b2e37e1d-fe34-4041-bdbd037c94f77403/010710_Acq_Financing_2010.pdf [https://perma.cc/5YWC-S8ZP]. 
in the market. The precise dates of when lawyers became concerned with these matters is unclear, but four possibilities stand out.

First, from a traditional contract law perspective, where lawyers are assumed to be reading judicial opinions and revising their contracts in response to the emerging case law, we would expect to see changes in contract language to appear starting in the 1990s. We refer to this as the "mid-1990s Case Law shock."

Second, experts in the field such as Steven Davidoff Solomon and Glenn West suggest that contract drafters in the private equity market began paying particular attention to the standard form in 2005-06 because of a set of important transactions and not because of any particular case outcomes. These two transactions, referred to in the industry as the "SunGard" and "Neiman Marcus" transactions, involved one of the first prominent instances of private equity sponsors providing a limited guaranty that a deal would go through (the "reverse termination fee"). ${ }^{32}$ Previously, private equity sponsors had structured the deal to insulate themselves from liability. But the increasing demand from the market for reverse termination fees-guarantees that quickly became commonplace after the SunGard and Neiman Marcus transactions-focused private equity sponsors on the possibility that they might be held personally liable for amounts greater than the termination fee. ${ }^{33}$ West writes, on the Weil Gotshal blog:

Indeed, before the SunGard and Neiman Marcus transactions in 2005 , not only was the acquisition vehicle the only party to the purchase and sale agreement, but there was no limited guaranty signed by the sponsor standing behind the reverse break fee. Indeed, there was no reverse break fee to stand behind and there was typically a funding out if the lenders did not fund the debt financing set forth in the debt commitment letter. And to mitigate any claims of piercing (however inappropriate they would have been), there developed a standard non-recourse provision that contractually bound the seller not to seek recourse

32. For a description of the SunGard transaction, see STEVEN M. DAVIDOFF, Gods at War: Shotgun Takeovers, Government By Deal and the Private Equity IMPLOSION 37-39 (2009) (noting the use of a "no-recourse" aspect of the guarantee in the SunGard transaction and the rapid change in industry practice towards the use of these reverse termination fees after 2005 from about ten percent of the deals in 2005 to eighty percent by 2008).

33. West \& Smeltzer, supra note 16, at 66; See Glenn D. West, Sungard and Neiman Marcus LBO Transactions-Increased Liability Risk to Private Equity Sponsors?, Weil, Gotshal \& Manges Private Equity Alert (June 1, 2005), https://www.weil.com/articles/sungard-and-neiman-marcus-lbo-transactions [https://perma.cc/TZT4-T4LR]. 
against the sponsor. That non-recourse provision is now incorporated into the limited guaranty of the sponsor, with a proviso that actually voids the guaranty if the seller seeks recourse against the sponsor for more than the guaranteed reverse break fee. A non-recourse provision is now not always set forth in the purchase and sale and agreement, but only in the limited guarantee. But the better practice is for it to appear in both. $^{34}$

We refer to the 2005 and 2006 transactions as the "2005-2006 Transaction Shock."

Third, prior research suggests that changes to standard form boilerplate occur in bursts when big negative financial events focus the attention of drafters on the need to produce a new standard form. ${ }^{35}$ A possible explanation here is that these negative events produce increased litigation because investors try to exit deals and their counterparts respond by suing for breach of contract. That type of litigation causes investors to focus on limiting their liability in the future. Based on this story, we would expect to see changes in the wake of the 2008 financial crisis that occurred during the period of our dataset. ${ }^{36}$ We refer to the impact of the financial crisis as the "2008 Financial Crisis Shock."

Fourth, in late 2011, attorneys Glenn West and Natalie Smeltzer published an article in the Business Lawyer, likely the most widely circulated business law publication in the country, on the pressing need to revise the No Recourse term. ${ }^{37}$ Between late 2010 and early 2012, West also spoke at a series of corporate counsel and bar association meetings about the need for revision. ${ }^{38}$

34. See Glenn D. West, Protecting the Private Equity Firm and its Deal Professionals from the Obligations of its Acquisition Vehicles and Portfolio Companies, WeIl Global Private EQUity WATCH (May 23, 2016), https://privateequity.weil.com/features/protecting-private-equity-firm-deal-professionalsobligations-acquisition-vehicles-portfolio-companies/ [https://perma.cc/KUD6-C3TS].

35. Generally, on the impact of large crises on contract change, see Stephen J. Choi, Mitu Gulati \& Eric A. Posner, The Evolution of Contract Terms in Sovereign Bonds, 4 J. Legal ANAL. 131 (2012).

36. For a discussion of the impact of the 2007-08 crisis on the private equity contract, see Matthew D. Cain et al., Broken Promises: The Role of Reputation in Private Equity Contracting and Strategic Default, 40 J. CORP. L. 565 (2015).

37. West \& Smeltzer, supra note 16.

38. According to information we obtained from West, there were at least five corporate counsel/CLE/bar association events at which he spoke on this topic between late 2010 and early 2012. E-mail from Glenn West to authors (Oct. 4 \& Oct. 9, 2019) (on file with authors). Further, the West/Smeltzer article received a Burton award for the article. Law360 Distinguished Legal Writing Awards-Law Firm (2012), THE BurTON AwARDs, https://www.burtonawards.com/winners/law360-distinguished-legal-writing-award- 
In sum, there are four events in the market that should, in theory, have induced attorneys to contemplate revising the No Recourse boilerplate. We use these four events to ask whether differences in identifiable agency costs affect the rate of change in the No Recourse contract term in private equity and public debt deals. To conduct this preliminary inquiry, we collected data on over six hundred transactions during the period January 1, 2005 to June 1, 2019 for public and private company deals that contained No Recourse clauses.

We found that the market universally followed a single standard No Recourse clause at the beginning of our dataset in 2005 that did not address the possibility of equity or fraud claims. We term this standard clause the "Old" clause. We found that the Old clause continued to dominate in public company deals through the entire time period of our dataset from 2005 to mid-2019 (although there were some versions of the No Recourse clause in public deals that did address equity and fraud claims that we discuss below as "Modified" clauses and "New" clauses). In contrast, we observed a dramatic shift away from the Old clause and toward the Modified and New clauses for private company deals after 2012.

In addition to testing whether the combined effects of agency costs from all sources matter for the rates of revision in boilerplate contract terms, we also attempt to isolate the impact of lawyer-side agency costs. Why should we expect to find that lawyers in commercial markets have inadequate incentives to revise boilerplate terms when external shocks negatively affect their clients' interests? In prior work, we found evidence suggesting that lawyers drafting sovereign debt contracts face a firstmover disadvantage in proposing revisions to standard boilerplate language. ${ }^{39}$ Lawyers are reluctant to change the language in standard terms because they cannot draft an entirely risk-free alternative to the current boilerplate language. ${ }^{40}$ Among other things, they have greater uncertainty about how courts will respond to the changes they do make. ${ }^{41}$ Thus, in the case of the No Recourse clause, changing the contract term by clarifying

winners-law-firms/ [https://perma.cc/FX8G-29D7]. Finally, the article with Smeltzer was published in the Business Lawyer, the journal of the American Bar Association, a copy of which goes to every member of the business law section and likely makes is the most widely circulated law journal. See AmERICAN BAR AsSOCIATION, The Business Lawyer, https://www.americanbar.org/groups/business_law/publications/the_business_lawyer/ [https://perma.cc/6P8Q-7BXV]. The revised clause that West and Smeltzer recommend in their November 2011 article was also subsequently (albeit in 2013) recommended as part of a package of reforms by the New York Bar Association. THE CORP. LAW COMM. OF THE ASS'N OF THE BAR OF N.Y.C., SAMPle CONTRACT BOILERPlate 18 (2013), https://www2.nycbar.org/pdf/report/uploads/SampleContractBoilerplate-March2013.pdf [https://perma.cc/9RCN-PYH9].

39. Choi, Gulati, \& Scott, The Black Hole Problem, supra note 3, at 6, 14.

40. Id. at 8-9.

41. Gulati \& SCOTT, supra note 8 , at Chapter 7. 
that the clause is explicitly intended to insulate shareholders and managers from all sources of liability might put unrevised clauses in prior contracts at greater risk of failing to protect against liability because of the absence of the new clarification. These "legacy contracts" costs increase as does market uncertainty: until the term is tested in litigation, there is greater uncertainty over how courts will interpret both the revised and original versions of the clause in question. In consequence of this heightened uncertainty, lawyers have greater reluctance to revise their clients' terms unilaterally. Changing a term poses the risk that the standard indenture will now be viewed as idiosyncratic, thus increasing learning costs. ${ }^{42}$

In prior work, we found that lawyers and other drafters can overcome these agency costs by coordinating on a change to the boilerplate that affects a large portion of the contracts that are issued after the external shock. ${ }^{43}$ The first-mover-disadvantage hypothesis thus predicts that these revisions will not occur in a significant way until the market participants can solve their collective action problem and coalesce around a new industry standard. ${ }^{44}$ While inertia costs for individual actors remains high, once the collective forms the costs are significantly diminished. ${ }^{45}$ To see whether the costs of coordination for drafting lawyers are correlated with contractual stickiness, we look both at the effect of coordinating eventssuch as the various bar association and continuing legal education (CLE) events led by attorney Glenn West in late 2011 - and at private company deals where client-side and investor-side agency costs are low. We compare those private company deals where at least one of the law firms associated with the private company deals was one of the top five ranked private equity law firms, indicating that law firms of sufficient size have the economies of scale to play a key role in modifying the market standard in the commercial contract setting compared with private company deals without such a law firm. We find both that the rate of revision in contract language changes significantly after the coordinating events and that there is a greater rate of revision in boilerplate terms for private company deals involving a top five ranked private equity law firm (consistent with lower coordination costs).

The remainder of the article proceeds as follows. Part I briefly describes the different types of No Recourse clauses and the relevant cases that suggest the benefits of revising the traditional version of the clause. Part II describes our tests and the data sources we used. Part III reports on the results of the tests. Part IV discusses implications. Part V concludes.

42. Id.

43. Choi, Gulati \& Scott, The Black Hole Problem, supra note 3, at 14, 59-61.

44. Id. at 14,59 .

45. Id. at 14 . 


\section{Clauses AND CASES}

The No Recourse provision in the early part of the 20th century was important because many states did not limit liability for equity holders in corporations but did allow parties to opt contractually for limited liability. ${ }^{46}$ An example of the standard opt out No Recourse clause, from a 1927 case, reads as follows:

No recourse under or upon any obligation, covenant, or agreement of this indenture, or of any purchase-money bond or coupon, or because of the creation of any indebtedness hereby secured, shall be had against any incorporator, stockholder, officer, or director of the company or any successor corporation, either directly or through the company, by the enforcement of any assessment or by any legal or equitable proceeding by virtue of any statute or otherwise. This indenture and the purchase money bonds are solely corporate obligations, and no personal liability whatever shall attach to or be incurred by the incorporators, stockholders, officers, or directors of the company, or any successor corporation, or any of them, because of the incurring of the indebtedness hereby authorized, or under or by reason of any of the obligations, covenants, or agreements contained in this indenture, or in any of the purchase-money bonds or coupons, and any and all personal liability either at common law or in equity, or by statute or Constitution, of every such stockholder, officer, or director, is released and waived as a condition of and as part of the consideration for the execution of this indenture and the issue of the purchase-money bonds. ${ }^{47}$

This version of the No Recourse clause (that we designate as the "Old" clause) was a standard feature of bond indentures from the turn of the century until the $1960 \mathrm{~s} .{ }^{48}$ From the 1960 s onward, the drafters of the Model Indenture Provisions continued to revise the language of the Old clause, ultimately reducing its length substantially, first in 1983 and then in 2000 , to the following forms that, importantly, did not explicitly address the possibility of equity or fraud claims:

46. See United States v. Stanford, 70 F. 346, 363 (9th Cir. 1895), aff'd, 161 U.S. 412 (1896); Preston v. Howell, 257 N.W. 415 (Iowa 1934). See also Note, The "No Recourse" Provision in Corporate Bonds and Indentures, 34 COLUM. L. REV. 107, 109-10 (1934).

47. Small v. Sullivan, 157 N.E. 261, 264-65 (N.Y. 1927).

48. See West \& Smeltzer, supra note 16, at Sections III \& IV (drawing from the case law in telling their story of the evolution of this clause). 
All liability described in the Securities of any director, officer, employee or stockholder as such, of the Company, is released. ${ }^{49}$ (1983 version)

and

A director, officer, employee or stockholder, as such, of the Company shall not have any liability for any obligations of the Company under the Securities or the Indenture or for any claim based on, in respect of or by reason of such obligations or their creation. ${ }^{50}$ (2000 version).

We designate all these versions of the No Recourse clause as the Old clause because they lack any reference to claims based in equity or fraud. The core of all variants of the Old clause is that the language does not explicitly bar veil piercing claims or other non-contractual claims against the principals and managers of the corporation. ${ }^{51}$

The first publicly discussed version of the No Recourse clause that addressed equity and fraud claims was proposed by West and Smeltzer in their 2011 Business Lawyer article. ${ }^{52}$ They drafted a new version of the No Recourse clause explicitly designed to exclude all potential sources of personal liability for principals and managers. ${ }^{53}$ In our data, we code instances of the West-Smeltzer clause as the "New" clause. It reads as follows:

[Except to the extent otherwise set forth in the other Transaction Documents], [a]ll claims, obligations, liabilities, or causes of action (whether in contract or in tort, in law or in equity, or granted by statute) that may be based upon, in respect of, arise under, out or by reason of, be connected with, or relate in any manner to this Agreement, or the negotiation, execution, or performance of this Agreement (including any representation or warranty made in, in connection with, or as an inducement to, this Agreement), may be made only against (and are those solely of) the entities that are expressly identified as parties in the preamble to this Agreement ("Contracting Parties"). No Person who is not a Contracting Party, including without limitation any director, officer, employee, incorporator, member, partner, manager, stockholder, affiliate, agent, attorney, or representative of, and any financial advisor or lender to, any Contracting Party,

\footnotetext{
49. $\quad$ Model Simplified Indenture, 38 Bus. LAw. 741, 772 (1983).

50. Revised Model Simplified Indenture, 55 Bus. Law. 1115, 1163 (2000).

51. E.g., Simons v. Cogan, 549 A.2d 300 (Del. 1988); LaSalle Nat'l Bank v. Perelman, 82 F. Supp. 2d 279 (D. Del. 2000).

52. West \& Smeltzer, supra note 16 .

53. Id. at 71-72.
} 
or any director, officer, employee, incorporator, member, partner, manager, stockholder, affiliate, agent, attorney, or representative of, and any financial advisor or lender to, any of the foregoing ("Nonparty Affiliates"), shall have any liability (whether in contract or in tort, in law or inequity, or granted by statute) for any claims, causes of action, obligations, or liabilities arising under, out of, in connection with, or related in any manner to this Agreement or based on, in respect of, or by reason of this Agreement or its negotiation, execution, performance, or breach; and, to the maximum extent permitted by law, each Contracting Party hereby waives and releases all such liabilities, claims, causes of action, and obligations against any such Nonparty Affiliates. Without limiting the foregoing, to the maximum extent permitted by law, (a) each Contracting Party hereby waives and releases any and all rights, claims, demands, or causes of action that may otherwise be available at law or in equity, or granted by statute, to avoid or disregard the entity form of a Contracting Party or otherwise impose liability of a Contracting Party on any Nonparty Affiliate, whether granted by statute or based on theories of equity, agency, control, instrumentality, alter ego, domination, sham, single business enterprise, piercing the veil, unfairness, undercapitalization, or otherwise; and (b) each Contracting Party disclaims any reliance upon any Nonparty Affiliates with respect to the performance of this Agreement or any representation or warranty made in, in connection with, or as an inducement to this Agreement. ${ }^{54}$

There is a substantial amount of new language in the West-Smeltzer clause. The particularly important additional provisions are the waiver of rights language and the sentences that explicitly mention agency theory, alter ego, piercing the corporate veil, and so on. The clause also specifies at the outset that liability - to the extent it is permitted - is only against those expressly named as contracting parties. This adds clarity to the older version that would designate those with liability as "the undersigned."

We also code for other instances we observed where the No Recourse clause is revised to address some of the new liability issues dealing with equity and fraud claims, but not as extensively as the West-Smeltzer version. We designate these as the "Modified" versions of the clause. Below, is an example of a Modified clause from a 2018 Stock Purchase agreement that specifies that there is no liability in "contract, tort, equity or otherwise", but has no explicit disclaimers with respect to veil piercing, alter ego, etc.:

54. Id. (emphasis added). 
This Agreement may only be enforced against, and any action, suit, claim, investigation, or proceeding based upon, arising out of or related to this Agreement may only be brought against, the Persons that are expressly named as parties to this Agreement. Except to the extent named as a party to this Agreement, and then only to the extent of the specific obligations of such parties set forth in this Agreement, no past, present or future shareholder, member, partner, manager, director, officer, employee, Affiliate, agent or Advisor of any party to this Agreement or any Subsidiary of the Company will have any liability (whether in contract, tort, equity or otherwise) for any of the representations, warranties, covenants, agreements or other obligations or liabilities of any of the parties to this Agreement or for any action, suit, claim, investigation, or proceeding based upon, arising out of or related to this Agreement. $^{55}$

In contrast to the New clause, the Modified clause lacks explicit disclaimers with respect to veil piercing, alter ego and the other versions of claims of that type. Given the tendency of courts, particularly in Delaware, to read these clauses narrowly and from a formalist perspective, the absence of a clear indication that the drafters wished for a different meaning supports the inference that this clause is less protective of the principals and managers than the West and Smeltzer version. ${ }^{56}$

\section{DATA}

We report the results of our inquiry into the relevance of coordination costs as an explanatory variable of both managerial and lawyer-side agency costs. Specifically, we report on changes to boilerplate No Recourse terms in the private company and public company setting. Our results are preliminary, and we only focus on top level results in this article. We hope to expand on these tests in a later study to take into account, among other factors, how the differences we observe vary by industry and the specific type of commercial contract. We also do not attempt to parse the deals as a function of which specific parties associated with the private or public company transactions benefit from the use of a New or Modified No Recourse provision. As an aside, our interviews with

55. Stock Purchase Agreement Byland Among Leggett \& Platt, Incorporated, EliteComfort Solutions, Inc. and EliteComfort Solutions LP, § 11.10 (November 6, 2018), https://1.next.westlaw.com/Xhtml/If9d88094e99e11e8a5b3e3d9e23d7429?originationCo ntext $=$ document\&transitionType $=$ PLDocumentLink\&contextData $=(\mathrm{sc}$. Search $)($ emphasis added).

56. For a discussion of the Delaware cases, see West \& Smeltzer, supra note 16, at $57-62$. 
lawyers who work on these deals suggests that the No Recourse provision is almost never the subject of negotiation. To the extent the language in the transaction changes, it is because the key firms involved in the transaction have changed the standard documents used in the transaction.

For our dataset, we collect a sample of public and private company deals from January 1, 2005 to June 1, 2019, that contained No Recourse clauses. We adopt a particular definition of a public company: if a company had stock listed on a national securities exchange, such as the New York Stock Exchange or Nasdaq, we counted it as a public company. ${ }^{57}$ And if it did not, that was categorized as a private company. We chose this particular definition of a public company because exchangelisted companies are more likely to have a dispersed shareholder base. In contrast, for companies not listed on an exchange, there are likely to be more concentrated owners, including often private equity firms, who will be better able to monitor their legal agents.

We assembled our dataset using two primary sources for the January 1, 2005 to June 1, 2019 period: (1) Westlaw's What's Market database which has compiled M\&A deals from 2010-19; (2) Bloomberg's SEC EDGAR database of exhibits attached to company 8-K filings, that we used for the 2005-10 period. The types of contracts contained in Westlaw and Bloomberg were Bond Indentures, Purchase and Sale Agreements, Stockholders Agreements, Trust Agreements, and Revolving Credit Agreements. While we leave to future research the examination of whether the dynamics of sticky boilerplate varies across these different categories of contracts, we believe that the key factors for the rate of revision and updating of the relevant contract term are (a) whether the company involved is private or public, which will affect the overall level of agency costs (particularly client and investor-side agency costs) and (b) whether there is an actor-such as a law firm that does extensive business in such contracts - that is able to function as a "spider" to coordinate the loose web of relationships among individual lawyers who otherwise may resist unilaterally revising boilerplate language, thereby reducing attorney-side agency costs. ${ }^{58}$ Once these two factors are taken into account, we believe

57. All of these equity listings were from US exchanges.

58. These informal relationships are commonly known as networks. Networks are mechanisms for coordination and cooperation between interdependent entities who operate in multilateral markets. Some networks deploy contractual mechanisms-whether in the form of a master contract as in the case of a franchise or a manufacturing supply chain, or a bureaucratic structure in the case of trade associations - that support network collaborations. These relationships have a "spider in the web"-a controlling entity or hierarchy at the center of the network that facilitates network formation and coordination. For further discussion, see Ariel Porat \& Robert E. Scott, Can Restitution Save Spiderless Networks, 8 Harv. Bus. L. ReV. 1 (2018); see also Stephen J. Choi \& Mitu Gulati, Innovation in Boilerplate Contracts, 53 EMORY L. J. 930 (2004) (reporting on the impact of industry dominant law firms in leading change to boilerplate contracts). 
that other factors, such as the type of contract, will affect the rate of change only marginally if at all.

From both databases we assembled a roughly equal number of randomly selected contracts with No Recourse provisions that covered roughly the same time periods for both private and public company transactions. In a number of these transactions, both public and private companies were involved. If one of the parties involved was private, we categorized the transaction as a private company transaction. For each transaction, we collected data on the type of No Recourse provisions, the deal amount, the deal type and the lawyers involved. To the extent the data we found from the foregoing sources was incomplete, we supplemented it with data from the Filings Expert database.

The contracts we obtained fall into two categories. The first category of contracts is "one-and-done" contracts for a single transaction. The second category of contracts is contracts that were part of a sequence of contracts for a single issuer raising capital across multiple transactions (we term these "repeat contracts"). We removed those repeat contracts that are part of a sequence that commenced prior to 2005. The following table reports the number of contracts for private company and public company transactions by year.

Table: Number of Private and Public Company Transactions by Year

\begin{tabular}{llll}
\hline Year & Private & Public & Total \\
\hline 2005 & 15 & 14 & 29 \\
2006 & 14 & 17 & 31 \\
2007 & 13 & 17 & 30 \\
2008 & 27 & 22 & 49 \\
2009 & 19 & 21 & 40 \\
2010 & 18 & 17 & 35 \\
2011 & 25 & 32 & 57 \\
2012 & 20 & 21 & 41 \\
2013 & 29 & 17 & 46 \\
2014 & 31 & 23 & 54 \\
2015 & 26 & 23 & 49 \\
2016 & 18 & 17 & 35 \\
2017 & 19 & 22 & 41 \\
2018 & 21 & 30 & 51 \\
2019 & 18 & 29 & 47 \\
\hline Total & 313 & 322 & 635 \\
\hline
\end{tabular}

In total, we collected data on 635 transactions, of which 313 involved a private company and 322 involved a public company. 


\section{ANALYSIS}

Our empirical strategy utilizes four shocks that could trigger a revision in the No Recourse clause that takes into account the exogenous events that had transpired - the mid-1990s Case Law Shock, the 20052006 Transaction Shock, the 2008 Financial Crisis shock, and the 2011 publication of the West/Smeltzer article and series of bar association/CLE presentations that occurred around that time where the need to revise the clause was discussed. We test whether agency cost differences owing to differences in the costs of monitoring and coordination between private company and public company transactions affect the rate of change of the contract term in the market.

Because our dataset runs from 2005 to mid-2019, we are unable to compare high versus low agency cost deals to test the mid-1990s Case Law shock. Prior to the time period of our dataset, Westlaw and Bloomberg as early as 1987 had reported a small number of contracts containing a No Recourse clause. However, the number of deals per year was sparse, with many years having either few or no transactions, indicating that Westlaw and Bloomberg did not comprehensively cover such contracts prior to 2005. Our understanding from talking to representatives at Westlaw/Bloomberg, however, is that the coverage significantly increased starting in 2005 and attempts to be comprehensive from 2010 onward. ${ }^{59}$ There were seven transactions that we could find from prior to 2005, ranging from 1987 to 2003 . All seven were private company transactions and all used the Old version of the No Recourse clause.

Based on this limited sample of transactions from before 2005, we find no evidence that the first shock, the mid-1990s Case Law shock, in and of itself caused the market to react by inducing revisions in the No Recourse clause for either private or public company transactions. While we do not know why our data sources contain only a small number of offerings prior to 2005, we have no reason to believe that the observations in the dataset prior to 2005 are not representative of the No Recourse clause in use during the pre-2005 time period. ${ }^{60}$ Moreover, the universal usage of the Old clause in 2005, the first year of our dataset, supports the prevalence of the Old clause prior to 2005 (see Figures 1 and 2). Further, as noted earlier, the private equity contract literature reports that No Recourse provisions became important in that industry starting in 2005

59. Importantly, from 2005 to 2010 , where the data coverage is not as comprehensive as that from 2010 onwards, there does not appear to be any bias in the subset of contracts that were scraped from SEC filings that would impact our results.

60. Our understanding from conversations with representatives at the data sources is that they are attempting to back fill documents from dates prior to 2005, but that this document collection is not an immediate priority given the lack of customer demand for older documents. 
with the increased use of the reverse termination fee. ${ }^{61}$ That said, from the limited pre-2005 data that we have, it appears that changes in case law alone were not sufficient to drive changes in boilerplate commercial contract terms.

To test the importance of overall agency costs in the rate of revision of contract terms, we utilize the 2005-2006 Transaction shock, the 2008 Financial Crisis shock and the 2011 West/Smeltzer article together with the CLE/bar association meetings. For each shock, we examine when New and Modified clauses appeared in the market for private versus public company deals. Figure 1 displays the mixture of the three types of No Recourse clauses (Old, New, and Modified) for each year from 2005 to 2019 for public company deals, including repeat contracts that are part of a sequence of contracts by the same issuer.

Figure 1. Public Non-Recourse Clauses

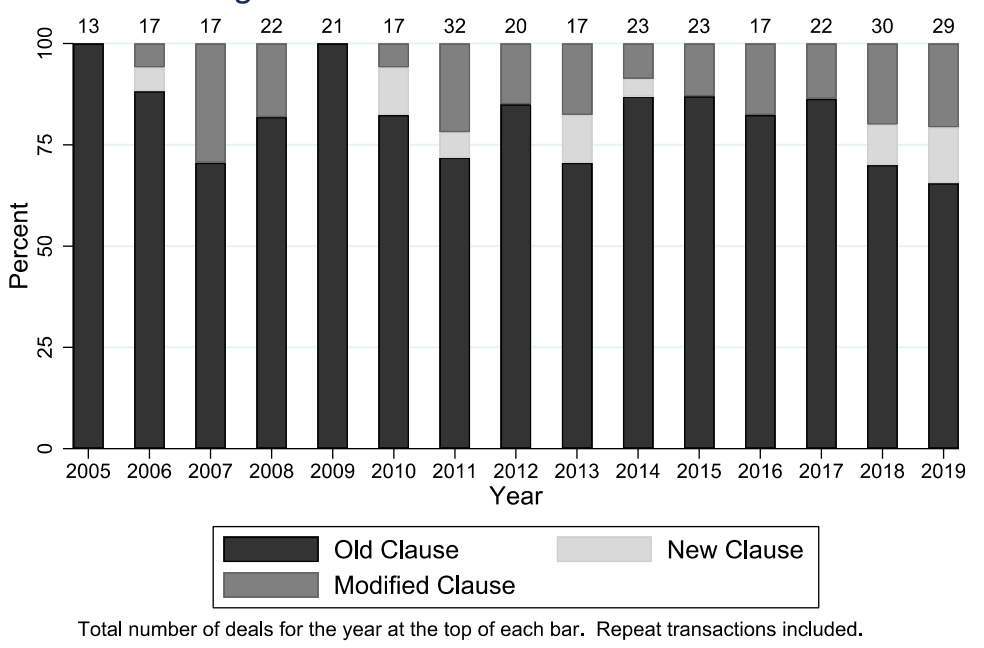

Note from Figure 1 that both the New and Modified clause are used in a minority of the public company deals starting in 2006. In no single year, however, are the New and Modified clauses either separately or in aggregate present in more than thirty-five percent of the transactions.

In comparison, Figure 2 displays the mixture of the three types of No Recourse clauses for year from 2005 to 2019 for private company deals, including repeat contracts that are part of a sequence of contracts by the same issuer. Note that unlike the public company deals, homogeneity exists in the market until 2009-only the Old clause is used in the transactions. ${ }^{62}$ From 2010, we see the introduction of the Modified clause

61. See DAVIDOFF, supra note 32, at 37-39.

62. That said, the caveat here is that Figure 2 only reports on what we found in our dataset. We do know from private equity literature that some of the deals have had 
in a fraction of the deals. Then in 2012, we see both the introduction of the New clause (the clause recommended by the West/Smeltzer article in

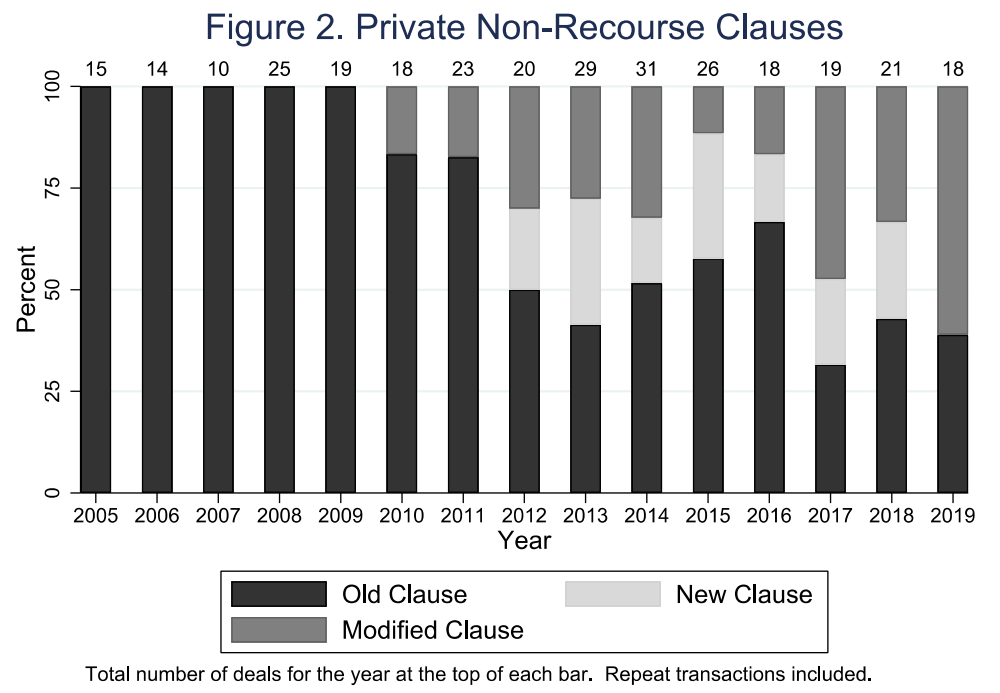

November 2011) and a rapid increase in the prevalence of both the New and Modified clauses, ultimately constituting a majority of the private company deals after 2012.

While there is some use of New and Modified clauses for public company deals, the use of these terms was sporadic for public company deals and never approached a majority usage in the market for any year in our sample period. Private company deals experienced a much different pattern. There appeared to be greater stickiness in the market prior to 2010 compared with public company deals, with $100 \%$ of the deals using the Old clause. Then in 2010 and 2011, we see a slight shift toward use of the Modified clause followed by a dramatic rise of both Modified and New clauses in 2012 and onward, accounting for roughly half of the clauses from 2012 to mid 2019. From 2012, the New or Modified clause is present in $52.5 \%$ of the private company transactions compared with only $22.3 \%$ of the public company transactions for the same time period (chi-squared test of the difference is significant at the $1 \%$ confidence level).

The patterns we observe in Figures 1 and 2 are consistent with the lower overall agency costs in private company deals resulting in greater incentives on the part of contracting parties after the coordinating events of the various bar association meetings discussing the need to revise this clause in late 2011. While neither the changes in case law in the mid-1990s nor the SunGard and Neiman Marcus transactions in 2005-2006 nor the

revised their clauses as early as 2005 (including in the famous SunGard transaction, see supra note 32), but we did not use those deal documents since they had not shown up in our data set. 
financial crisis in 2008 were enough to spur widespread change, the publication of the West/Smeltzer article and the various bar association/CLE events does appear to drive change, in particular in the context of private company transactions. Where agency costs are greater, however, as for public company deals, the publication of the West/Smeltzer article and the CLE/bar association meetings do not result in a major change in the No Recourse clause. For public company deals, there is a small shift toward the New and Modified clause from 2006 onward, but the market remains predominantly stuck on the Old clause up to the end of our study in mid-2019. In comparison, private company deals, with lower agency costs, shift later, only after the coordinating events of late 2011. Once the shift occurs, however, the market moves quickly, with the New and Modified clause together constituting roughly half of the clauses in new deals from 2012 onward.

One issue with our comparison of private company and public company transactions in Figures 1 and 2 is that many of the contracts were from repeat transactions by the same corporate entity. We observed extreme stickiness in the No Recourse clause in these repeat contracts. For private company transactions, 109 of the 313 contracts were part of a sequence of repeat contracts. That is, the documents would specify that they were borrowing pursuant to a document filed with the SEC for an earlier deal. In total, there were 12 such sequences for private company transactions with a mean of 9.1 contracts per sequence. In each of the 12 sequences, the initial indenture contract contained the Old clause and all subsequent repeat contracts copied this same clause. A similar pattern exists for the public company transactions. Out of the 322 public company transactions, 123 were part of a sequence of repeat contracts. In total, there were 24 such sequences with a mean of 5.2 contracts per sequence. As with the private company transactions, the initial contract in a sequence used the Old Clause and all subsequent repeat contracts also used the same clause.

Because of the extreme stickiness in sequences of repeat contracts, the presence of the repeat contracts may mask changes in one-and-done and initial contracts in a sequence of contracts. To examine the contracts where we expect changes to happen, we remove all repeat contracts in sequences of contracts other than the first contract in the sequence. This left us with 216 contracts for private company transactions (with 204 oneand-done contracts and 12 initial contracts for a sequence) and 221 contracts for public company transactions (with 197 one-and-done contracts and 24 initial contracts for a sequences).

Figures 3 and 4 graph the mix of No Recourse clauses by year for private company and public company transactions excluding repeat contracts other than the initial contract in the sequence. Note that even without repeat contracts, the Old clause remains the majority clause for transactions in all years for public company transactions. In comparison, 
the shift away from the Old clause and toward the Modified and New clauses is even more pronounced for private company transactions once

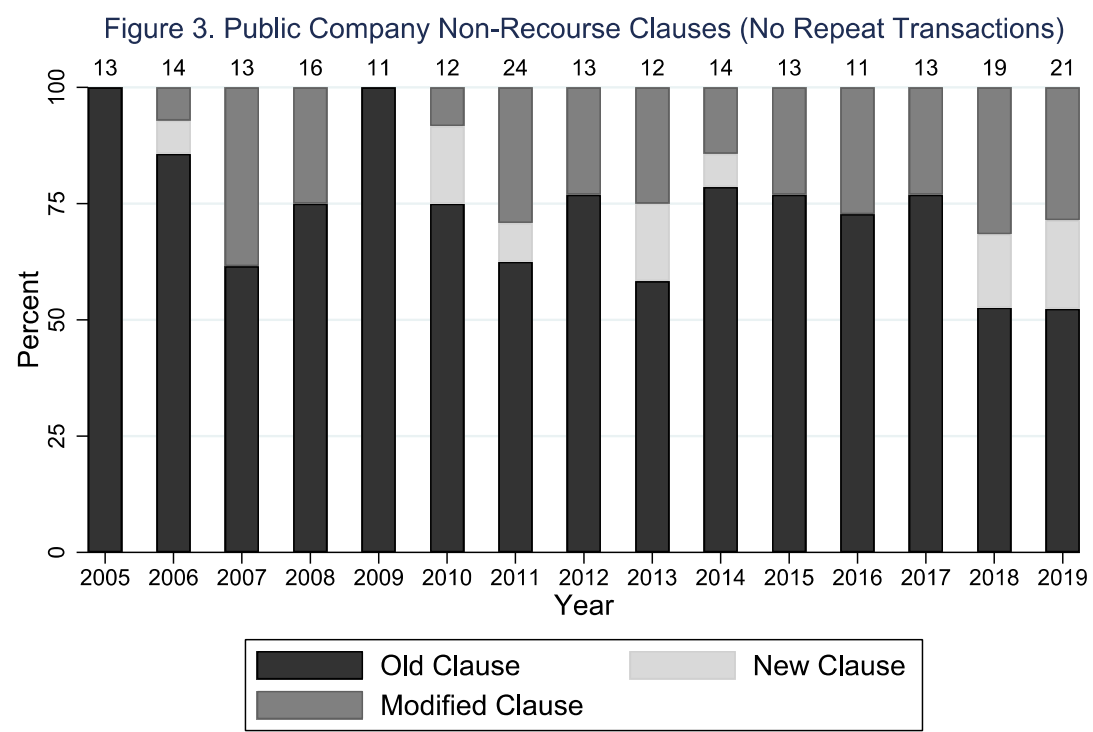

Total number of deals for the year at the top of each bar.

Figure 4. Private Company Non-Recourse Clauses (No Repeat Transactions)
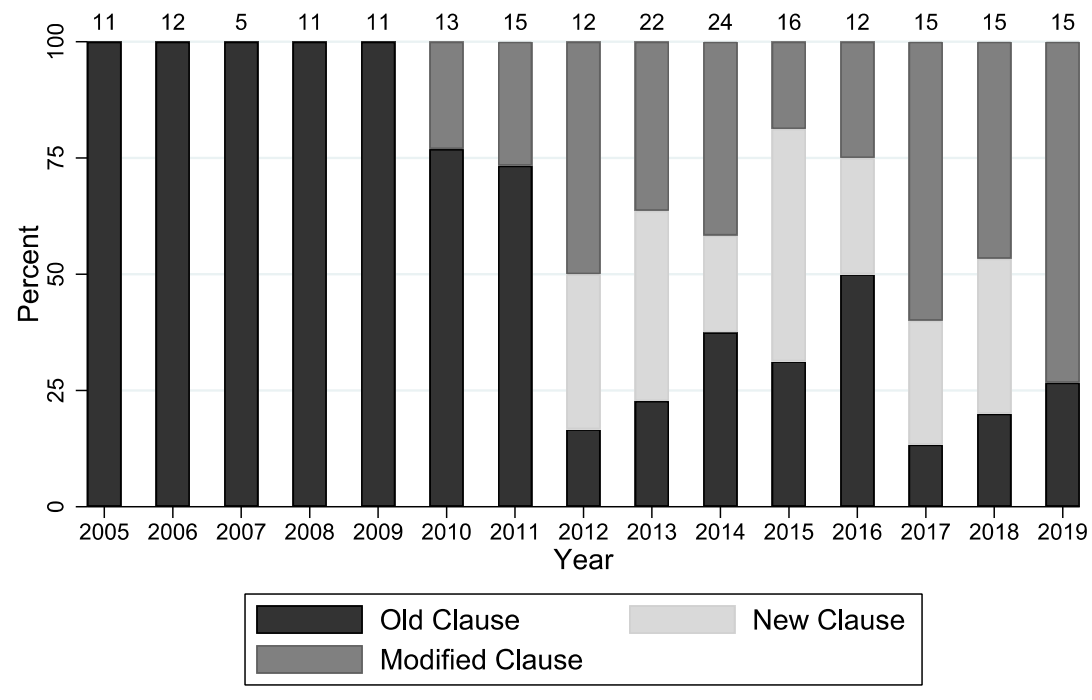

Total number of deals for the year at the top of each bar.

the repeat contracts are removed. Without the repeat contracts, from 2012 onward the New or Modified clause is present in $71.4 \%$ of the private company transactions compared with $34.9 \%$ of the public company transactions (chi-squared test of the difference is significant at the $1 \%$ confidence level). 
To focus more intently on the separate importance of lawyer-side agency costs, we split the private company deals between those with a top private equity law firm present in the deal and those without such a law firm. We define a top private equity law firm as a law firm ranked as one of the top 5 private equity law firms by Vault in $2020 .^{63}$ These firms included Kirkland \& Ellis LLP, Simpson Thacher \& Bartlett LLP, Latham \& Watkins LLP, Skadden, Arps, Slate, Meagher \& Flom LLP, and Cravath, Swaine \& Moore LLP. We predict that a top private equity law firm will have the economies of scale and incentive to invest as a "spider" in coordinating the network of lawyers to developing a new standard No Recourse clause and in recommending this term to clients in private company deals.

We compare the mix of No Recourse clauses over time for one-anddone contracts (including the first contract in a sequence of contracts) for private company transactions that did and did not involve a top private equity law firm. Many of the transactions involved multiple law firms. We defined a transaction as involving a top private equity law firm if at least one of the firms involved in the transaction was one of the top five ranked firms by Vault in 2020 .

63. See Best Law Firms for Private Equity, VAULT, https://www.vault.com/bestcompanies-to-work-for/law/best-law-firms-in-each-practice-area/private-equity [https://perma.cc/73MX-SU7M]. We assume that the top five firms in the 2020 Vault ranking were among the top private equity firms throughout our sample time period from 2005 to 2019. We also ran the tests using the ranking of top five firms from Chambers and Partners, which uses a different method of ranking (client surveys, as opposed to law student surveys). In that ranking, Clifford Chance LLP and Weil Gotshal \& Manges LLP replace Skadden, Arps, Meagher \& Flom LLP and Cravath, Swaine \& Moore LLP. For the latest Chambers ranking, as of this writing, see https://chambers.com/guide/global?publicationTypeId=2\&practiceAreaId=775\&subsecti onTypeId=1\&locationId=225 [https://perma.cc/R7P3-68BS]. The results were essentially the same. There are other rankings of the top law firms as well that invariably list the same set of firms in their top categories, such as US News. 
Figure 5 depicts the mix of different No Recourse clauses by year for one-and-done and the initial contract in a sequence of contracts for private company deals involving at least one top private equity law firm. Note from the figure that from 2012 onward, the Modified or New clause dominates in the market. From 2014 onward, no private equity deal involving a top private equity law firm uses the Old clause. There is a $100 \%$ shift away from the Old clause.

Figure 5. Private Company Non-Recourse Clauses (Top 5 Law Firm)

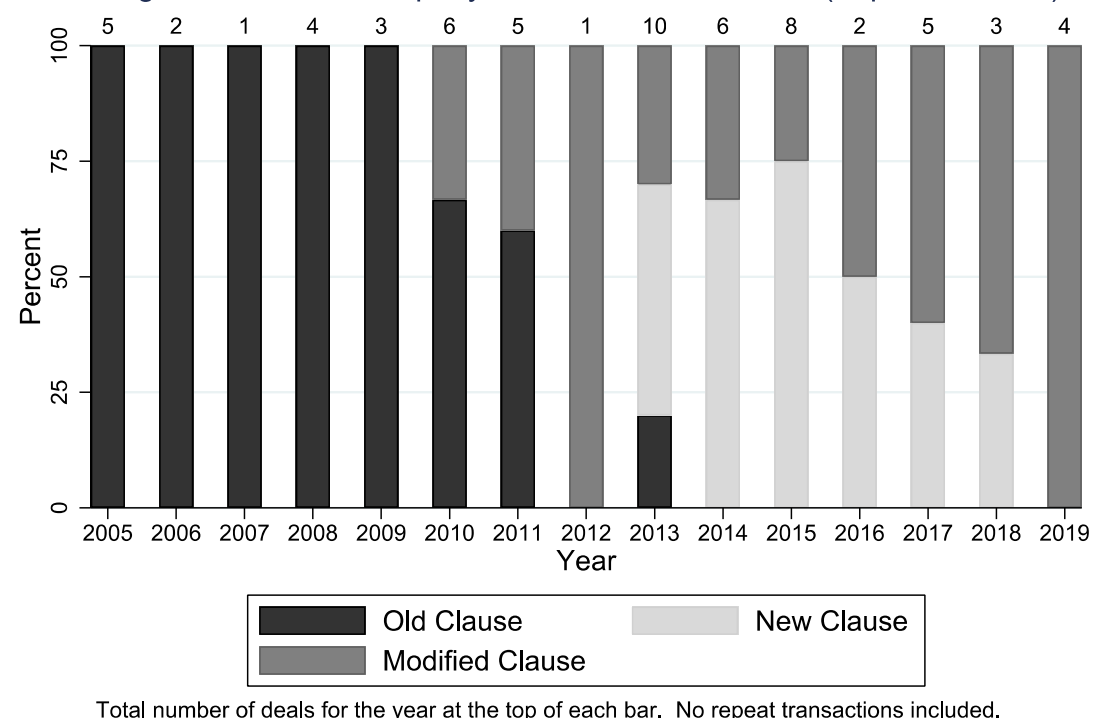

In comparison, we depict the mix of No Recourse clauses by year for one-and-done contracts and the initial contract in a sequence of contracts for private company deals without any top private equity law firm in Figure 6. While there is a shift away from the Old clause toward the Modified and New clauses from 2012 onward, note that the Old clause is still used frequently in deals through the end of our dataset in mid-2019. Indeed, in 2015 and 2016, the Old clause is the majority clause in the market. From 2010 onward, the New or Modified clause is present in $82.0 \%$ of the private company transactions with a top private equity law firm compared with only $56.0 \%$ of the private company transactions without a top private equity law firm (chi-squared test of the difference is significant at the $1 \%$ confidence level). Our evidence indicates that the presence of a top ranked private equity law firm is correlated with a much higher rate of change away from the Old clause and toward the New or Modified clause after the 2008 Financial Crisis shock. 
Figure 6. Private Company Non-Recourse Clauses (No Top 5 Law Firm)

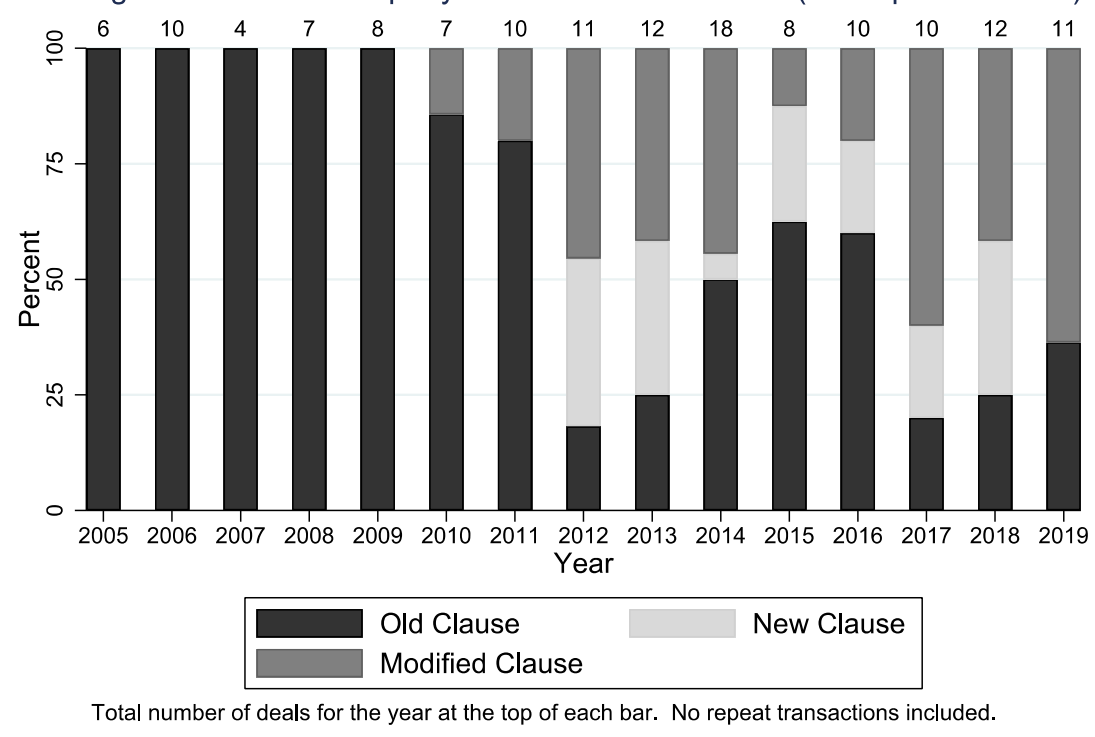

\section{IMPLICATIONS}

This preliminary study was designed to advance our understanding of the ways that agency costs might affect contract term stickiness in boilerplate commercial transactions. To that end, we sought to examine the impact of overall agency costs on the rate of change of boilerplate contract terms by comparing public company deals, a context with high agency costs, with private company deals, a context with low agency costs. We also isolated the effects of lawyer-side agency costs by comparing private company deals with a top five private equity attorney and deals without such an attorney.

Our prior work in sovereign debt contracting showed that a key source of agency costs was the reluctance of agents - the bankers, debt managers, and lawyers - to act unilaterally to revise boilerplate terms that were accepted as the standard form in a large multilateral market. This first-mover disadvantage stemmed from concern that any revision might be viewed as idiosyncratic in the market and thus, by increasing learning costs, increase the front-end costs of issuing the debt transaction. Moreover, idiosyncrasy increases the risk of misinterpretation by courts as well as the risk of a negative signal. In the current study, the risk of that same idiosyncrasy may have deterred revisions to No Recourse terms in new contracts that might then have resulted in the failure of contracts containing the old language to insulate parties from liability. The evidence here shows that important revisions to the standard boilerplate did not 
occur widely until the relevant actors were able to coordinate on a global change that the market could accept as the new standard.

Our current study, while preliminary, offers evidence that coordination in loosely organized networks, such as networks of transactional lawyers, is facilitated to the extent that there is a "spider in the web" - a controlling entity or hierarchy at the center of the network that facilitates network formation and maintains stability. ${ }^{64}$ Here we have evidence that supports the coordinating function of the spider in the web. With the caveat that we can show only correlation, not causation, a series of continuing education/bar association sessions at which an eminent senior lawyer advocated for a revision of a contract term, supported by the publication of an article in a widely circulated journal seems to have been key in inducing change. Further, the biggest and fastest changes in the boilerplate occurred in deals where the top law firms in the industry were involved. The large law firms that dominate the private equity market appear to have functioned much more effectively to coordinate the changes to the No Recourse clause that better protected their clients' interests than did lawyers representing public companies who operated without the benefit of a coordinating spider.

Noteworthy here is that none of the lawyers we spoke to in the context of this project, including the lawyer whose efforts seem to have been instrumental in inducing change, predicted what we found. They speculated that either the SunGard and Neiman Marcus transactions or the 2008 financial crisis might have been the catalysts for significant change in the market. As an aside, none of our respondents thought that the case law we cite was likely to induce change in drafting practices - contrary to what the standard legal and economic theory would predict.

The relevance of the spider in coordinating revisions to inefficient boilerplate can be observed in other settings as well. Returning to the sovereign bond market: if the market participants had acted together, they could have overcome many of the reasons for inertia noted earlier. But coordinating the efforts of participants in multilateral markets to create a functioning network is challenging. To be sure, some multilateral markets deploy mechanisms - whether in the form of a master contract as in the case of franchises or a bureaucratic structure in the case of trade associations - that support network collaborations. ${ }^{65}$ But the sovereign

64. Porat \& Scott, supra note 58, at 15-16; Robert E. Scott, The Paradox of Contracting in Markets, 100 LAW \& CONTEMPORARY PROBLEMS (forthcoming 2020), https://papers.ssrn.com/sol3/papers.cfm?abstract_id=3561705.

65. See e.g., Lisa Bernstein, Private Commercial Law in the Cotton Industry: Creating Cooperation Through Rules, Norms, and Institutions, 99 MicH. L. REV. 1724 (2001); Lisa Bernstein, Merchant Law in a Merchant Court: Rethinking the Code's Search for Immanent Business Norms, 144 U. PA. L. REV. 1765, 1771-77 (1996) (discussing rules 
bond market, as well perhaps as the corporate bond market we study here, lack any centralizing spider to mandate changes in contract language. ${ }^{66} \mathrm{On}$ the contrary, as our data show, the private equity market, particularly where a top law firm is involved in a deal, is more analogous to the case of the market for derivatives, where the ISDA Determination Committees serve as the spider organizing regular updating of terms in the master contract. ${ }^{67}$

\section{CONCLUSION}

We emphasize once more that the results of this preliminary study are only suggestive. Despite these caveats, we conclude with two claims. First, the issues raised by the existence of large law firms as a possible coordination mechanism in connection with lawyer networks deserve a more prominent place in legal scholarship. Second, the evidence simply cannot be ignored that coordination difficulties are an important part of the explanation of why standard terms in large market commercial contracts are slow to change in response to significant external shocks. The demand for an increased scholarly focus on the nature and extent of network solutions to the problems of sticky contract terms is justified by the subject's practical significance, its normative importance and its intellectual interest.

of the National Grain and Feed Association, which requires that all disputes among members must be submitted to the Association's arbitration system).

66. Failure of coordination is the best explanation of why no changes in contract language occurred in the case of Argentina's sovereign debt for over three years after the Second Circuit Court of Appeals had issued an interpretation that put all future efforts to restructure the Argentine bonds at risk. The individual interests of the key market participants were inconsistent with their collective interests. Any revision to the clause at issue - the pari passu clause that was interpreted to foreclose a restructuring of Argentina's debt - had to be "settled" among the key parties, since the market demanded "standard" legal terms that minimized the ex-ante costs of placing the bonds in the market. Coordination did not occur, therefore, until a conference at Columbia Law School in early October 2014 gathered the key parties together. The Columbia meeting appeared to make clear to those present that coordination attempts were not proceeding smoothly, and the result was a subsequent meeting of the key players at the offices of the New York Federal Reserve Bank at which coordination did occur. For further discussion, see Stephen J. Choi, Mitu Gulati \& Robert E. Scott, Contractual Arbitrage in OXFORD HANDBOOK OF INTERNATIONAL GOVERNANCE (Jerome Sgard et al. eds. 2020) (forthcoming).

67. Thus, for example, the ISDA Master Contract is updated frequently by the International Swaps and Derivatives Association. The ISDA Determination Committees are a central authority with power to endorse and update the terms in derivative contracts, empowered to make official, binding determinations regarding the existence of "credit events" and "succession events" (such as mergers), which may trigger obligations under a credit default swap contract. See Scott, supra note 64, at n.21. 